УДК 351.477.094

\title{
Значення інституту звернень громаАян в умовах наростання загроз національній безпеці
}

\author{
А.В. КАПУАОВСЬКИЙ \\ Національна акалемія державного управління при Презилентові України, \\ м. Київ, Україна, E-mail: kapulovskiy_artem@ukr.net
}

\begin{abstract}
Авторське резюме
У статті наведено нормативно-правове та наукове обгрунтування необхідності розвитку інституту звернень громадян в умовах явних внутрішніх та зовнішніх загроз національній безпеці держави. Зроблено спробу побудови належної моделі управління суспільними процесами в умовах загроз національній безпеці країни, при якій ключове значення відіграє думка суспільства. Справа в тім, що успішне вирішення проблеми залучення широкої громадськості до процесу підготовки та прийняття політичних рішень потребує не лише наявності конституційно закріплених прав і свобод громадян та політичних інститутів, сформованих демократичним шляхом, але й різноманітності форм та засобів впливу населення на діяльність органів влади.

Поряд з цим в умовах неоголошеної так званої «гібридної» війни, за якої бойові дії ведуться локально - на певній частині території держави, а всі інші державні та недержавні інституції функціонують у звичайному для них режимі, відстеження можливих загроз національній безпеці держави та чинників, які породжують такі загрози, повинно здійснюватися за допомогою як суто військових, так і цивільних засобів та методів. При цьому, одним з найбільш дієвих цивільних засобів відстеження таких загроз є, на мою думку, прийом звернень громадян, їх опрацювання та вжиття відповідних заходів реагування.
\end{abstract}

Ключові слова: національна безпека, державна безпека, права людини, органи державної влади, інтереси суспільства.

\section{Significance of the institute of appeals under the conditions of increasing threats to national security}

\author{
A.V. KAPULOVSKYI \\ National academy for public administration under the President of Ukraine, \\ Kyiv, Ukraine, E-mail: kapulovskiy_artem@ukr.net
}

\begin{abstract}
The article deals with the regulatory and scientific foundation for the development of the institute of citizens' treatments in terms of obvious internal and external threats to national security. An attempt to construct an applicable model of management of public processes in terms of threats to national security, in which public opinion plays a key value. The fact that a successful resolution of problem of public participation in the preparation and acceptance of political decisions requires not only the presence of the constitutionally enshrined rights and duties and political institutions formed democratically, but also a variety of forms and ways of influencing in the activities of public authorities.

At the same time, in a not declared, the so-called »hybrid» war, in which warfare are conducted locally - in some parts of the state and all other public and private institutions function in usual mode, tracking of possible threats to national security and factors that give rise to such threats should be carried out by means of both cleanly military, and civil means and methods. Thus, one of the most effective civil means of tracking such threats are the reception of citizens' treatments, their processing and the adoption of appropriate response measures, in my opinion.
\end{abstract}

Keywords: national security, public safety, human rights, public authorities, public interest.

(c) А.В. Капуловський, 2015 
Постановка проблеми. Формування та втілення державної політики відбувається через прийняття управлінських рішень. Фактично процедуру вироблення управлінських рішень можна визначити, як процес трансформації вимог різноманітних груп та громадян у прийнятні для суспільства засоби та методи регулювання соціальних відносин.

При цьому основними суб'єктами прийняття управлінських рішень є громадяни, представники громадських організацій, асоціації, політичні партії, професійні спілки, представники влади.

Питання участі громадян у процесі вироблення управлінських рішень зводиться до проблематики громадянського суспільства, якості та ефективності взаємодії його інститутів 3 владними установами. Адже саме інститути громадянського суспільства (громадські організації, профспілки, неурядові дослідні центри) є «сукупністю відносно автономних, авторитетних недержавних структур, які складають систему конструктивних противаг і стримувань для структур державної влади», та посередником у діалозі між громадянином та владою [7, с. 205].Особливої уваги заслуговує така форма участі громадян у процесі державного управління, як «звернення громадян». Очевидно, що якби звернення громадян не було взагалі, державному апарату було б важче збирати інформацію про проблеми населення та, відповідно, важче стежити за змінами ситуації й оперативно на них реагувати. Це було виявлено давно і завжди відзначалося спеціалістами з державного управління.

3 огляду на це та беручи до уваги останні події в Україні вбачається необхідність у визначенні ролі участі громадськості у процесі державного управління, у тому числі шляхом надсилання звернень, за умови явних внутрішніх та зовнішніх загроз національній безпеці держави. Виокремлення вказаної ролі дасть змогу сформулювати дієву модель управління суспільними процесами, що забезпечувала б належний рівень національної безпеки.

Аналіз досліджень i публікацій. Щодо забезпечення національної безпеки, а також існуючих загроз такій без- пеці та їх класифікації, то розв'язанню вказаних проблем присвячено цілий ряд досліджень провідних вітчизняних і зарубіжних учених. В Україні цим проблемам були присвячені роботи Г.П. Ситника, В.І. Абрамова, Ю.І. Римаренка, Г.Г. Почепцова, Г.М. Перепелиці, С.I. Пирожкова, Н.Р. Нижник, В.П. Горбуліна, I.Ф. Бінька, О.С. Бодрука, О.В. Копана та інших.

Поряд із цим проблеми створення системи безпеки становили предмет дослідження таких західних науковців, як: Т. Гоббс, Н. Макіавеллі, Ш. Монтеск'є, С. Брауна, У. Ліппмана, М. Каплана, 3. Бжезінського, Г. Кіссінджера, Г. Моргентау, С. Хантингтона, С. Хоффмана, Н. Спікмена та інших. Ceред російських дослідників слід назвати П. Белова, К. Гаджиєва, О. Дугіна, В. Манілова, Ю. Тихонравова, В. Ярочкіна та інших. У своїх працях вказані вчені детально дослідили теоретичну основу національної безпеки в окремих її сфеpax (політичній, економічній, екологічній, військовий).

Питання ж залучення громадян до процесу державного управління активно вивчається у політичній науці на сучасному етапі. Серед зарубіжних дослідників цього напряму варто виокремити наукові доробки Г. Алмонда, Б. Барбера, С. Верби, Л. Даймонда, Дж. Ф. Ціммермана та ін. Проблема аналізу форм взаємодії громадян та органів влади останнім часом набула популярності і в колі вітчизняного експертного середовища, а саме: вказані питання розкриваються в працях А. Нікітіна, А. Ткачук, Є. Фішка, Ю. Ганущак, I. Підлуської та ін. Крім того, слід зазначити, що вирішити проблемні питання реагування на виклики, небезпеки та загрози національній безпеці у своїх працях намагаються такі вітчизняні вчені, як Д.Я. Кучма, А.В. Дацюк, В.Ю. Богданович, А.І. Семенченко.

Водночас, прослідковується дефіцит наукових напрацювань 3 питань участі громадян у процесі державного управління, за умови явних внутрішніх та зовнішніх загроз національній безпеці.

Метою дослідження є з'ясування значення інституту звернень громадян шля- 
хом аналізу факторів впливу суспільноі думки на прийняття органами державної влади управлінських рішень в умовах наростання внутрішніх та зовнішніх загроз національній безпеці.

Виклад основного матеріалу. Україна, що виступає за створення системи загальноєвропейської колективної безпеки, вважає участь у ній важливим компонентом національної безпеки та сприяе створенню надійних міжнародних механізмів та загальноєвропейської структури безпеки на двосторонньому, регіональному і глобальному рівнях 3 метою зміцнення довіри і партнерства на основі принципів взаєморозуміння і відкритості.

При цьому необхідною умовою для досягнення вказаної цілі є формування власної дієвої системи національної безпеки, спроможної на ефективне реагування викликам та внутрішнім і зовнішнім загрозам.

Так, для досягнення вказаних цілей, а також для реалізації сучасної політики національної безпеки необхідним є вжиття заходів щодо відстеження змін, які відбуваються в державі з урахуванням внутрішніх і зовнішніх чинників впливу, визначення обсягів та пріоритетності загроз національним інтересам для розроблення та вжиття заходів, що виходять за межі традиційних механізмів, та методів виявлення загроз національним інтересам на початкових стадіях їх виникнення.

Слід відзначити, що в умовах неоголошеної війни, за якої бойові дії ведуться локально - на певній частині території держави, а всі інші державні та недержавні інституції функціонують у звичайному режимі, відстеження можливих загроз національній безпеці держави та чинників, які породжують такі загрози, повинно здійснюватися за допомогою не лише суто військових, але й цивільних засобів та методів.

Національна безпека в широкому розумінні цього слова, за умов такої неоголошеної війни, за умов геноциду українського народу, набуває дещо нового якісного змісту. Ї̈ можна визначити як можливість громадських систем країни забезпечити високий рівень життє- діяльності нації і її конкурентоспромож ності у взаємовідносинах 3 зовнішнім світом з метою надійного буття і сталого розвитку. Задля цього необхідним є створення в суспільстві таких умов, які на кожному конкретному історичному етапі допомагали б: інтелектуальній i практичній мобілізації його структурних можливостей для влаштування (пристосування) суспільства; оптимальному використанню цих можливостей в інтересах і для цілей підвищення соціальної ефективності та конкурентоздатності країни; орієнтації на запобігання воєнних, екологічних, економічних та інших загроз, на стимулювання соціально-економічного, культурного й іншого розвитку суспільства.

Основним завданням інститутів держави в даний час є створення умов (перш за все, політично-інституційного характеру) для прогресу та оборони держави, відстеження та відповідного реагування на загрози національним інтересам держави, а суспільство, зі свого боку, повинно керуватися орієнтирами, стимулами і ресурсами для розвитку.

При цьому одним 3 найбільш дієвих цивільних засобів відстеження як внутрішніх, так і зовнішніх загроз національній безпеці $є$ прийом звернень громадян та їх опрацювання органами державної влади.

Справа в тім, що формування та втілення державної політики, зокрема й у сфері національної безпеки, відбувається через прийняття управлінських рішень. Останнє $є$ технологічною компонентою політичної влади, що пов'язана з управлінням суспільними процесами. У сучасній політичній науці даний аспект державного управління розглядається у безпосередньому взаємозв'язку 3 інтересами та діяльністю численних суб'єктів суспільно-політичного життя.

Фактично процедура вироблення управлінських рішень - це «процес трансформації вимог різноманітних груп та громадян у прийнятні для суспільства засоби та методи регулювання соціальних відносин» [6, с. 392]. Основними суб'єктами прийняття управлінських рішень є громадяни, представники громадських організацій, асоціації, політичні 
партії, професійні спілки, представники влади.

Отже, питання участі громадян у процесі вироблення управлінських рішень зводиться до проблематики громадянського суспільства, якості та ефективності взаємодії його інститутів 3 владними установами. Оскільки інститути громадянського суспільства (громадські організації, профспілки, неурядові дослідні центри) є «сукупністю відносно автономних, авторитетних недержавних структур, які складають систему конструктивних противаг і стримувань для структур державної влади», та посередником у діалозі між громадянином i владою [7, с. 205]. Зрештою, результативність взаємодії населення й держави безпосередньо залежить від рівня інституціоналізованості суспільно-політичної діяльності громадян, що, у свою чергу, можуть забезпечити саме організації громадянського суспільства.

Правовою основою залучення громадськості до процесу прийняття управлінських рішень є передусім Конституція України. Зокрема, у статті 38 Основного Закону визначено право громадян на участь в управлінні державними справами, а у статті 40 цього ж Закону зафіксовано право на письмові та колективні звернення до органів влади та місцевого самоврядування [4].

Порядок і умови розгляду звернень громадян органами державної влади в Україні врегульовано законами та підзаконними нормативно-правовими актами, головними з яких є Закони України «Про інформацію», «Про звернення громадян», «Про доступ до публічної інформації» .

Очевидно, що якби звернень громадян не було взагалі, державному апарату було б тяжче збирати інформацію про проблеми населення та, відповідно, важче стежити за змінами ситуації й оперативно на них реагувати. Це було виявлено давно і завжди відзначалося спеціалістами з державного управління.

В сучасних умовах в демократичній державі звернення громадян можуть бути не тільки засобом правового захисту, але й формою реалізації права громадян на участь в управлінні справами дер- жави, закріпленої в Загальній декларації прав людини 1948 року та Конституції України [2, 4].

Очевидно, що громадянин, направляючи звернення, ставить перед собою мету добитися від відповідних органів державної влади здійснення деяких значущих дій. Звернення - завжди усвідомлений акт, тому що той, хто не ставить перед собою ніякої цілі, навряд би став звертатися в органи державної влади.

Крім того, звернення не зв'язане 3 публічною владою безпосередньо. Воно надходить до владних структур від громадян, із сфери соціальної, побудованої на логіці компромісу, а не ієрархії. Навіть якщо дивитися з боку авторитарного підходу до звернення, воно все одно залишається нейтральним у відношенні до влади як такої. Автор звернення може виступати і як прохач, і як партнер (це залежить від підходу і особливостей системи), але він не є ні «начальником», ні «підлеглим» у відношенні до того, кому надсилається звернення. Таким чином, якщо спиратися на сформоване визначення громадянської участі, то стає повністю зрозуміло, що звернення наділене всіма характерними йому ознаками.

Інститут звернення громадян в органи влади виконує три важливі функції: правозахисну, інформаційну і комунікаційну. Сутність першої полягає в тому, що звернення як юридичний інститут $\epsilon$ одним із засобів захисту прав громадян: вони дозволяють попередити правопорушення, а якщо воно вже здійснене - ліквідувати його наслідки і поновити порушене право. Друга функція полягає в тому, що звернення громадян є для державного апарату цінним джерелом інформації про проблеми громадян. Третя полягає в наступному: звернення громадян можуть бути засобом комунікації між державою і громадянами, слугувати свого роду каналом зв'язку, за допомогою котрого громадяни можуть впливати на владні рішення, брати участь у процесі їх прийняття. Її також можна назвати партисипаторною. Інформаційна функція інституту звернення громадян не має великого значення з точки зору інтересів окремих громадян. Громадянин, надсилаючи звернення, в більшості випадків 
прагне до того, щоб отримати допомогу у вирішенні своїх особистих питань. Від того, чи використає державний орган потрібну для своєї роботи інформацію, становище громадянина ніяк не зміниться. Але, з точки зору державного управління, інформаційна функція дуже важлива та значима, адже звернення надсилають, перш за все, громадяни, котрі зачіпають ті чи інші проблеми, при цьому вирішити їх самостійно вони вже не можуть. Аналіз звернень, відповідно, може дати цінну інформацію про проблеми й труднощі, що виникають у громадян, а саме головне, в умовах наростання загроз національній безпеці держави - інформацію про наявність таких загроз, джерела їх виникнення та можливі способи їх ліквідації.

Так, лише з урахуванням інформації, зібраної зі звернень громадян та опрацьованої відповідними державними структурами, повинно здійснюватися формування основоположних принципів системи забезпечення національної безпеки, визначення головних методів та засобів реагування на внутрішні та зовнішні загрози інтересам держави, суспільства та окремого індивіда.

Отриману зі звернень громадян інформацію орган державної влади (посадова особа) має реалізувати, в тому числі й під час використання своїх організаційно-розпорядчих функцій. При цьому необхідним $€$ дотримання тієї ж мети забезпечення якомога вищого рівня національної безпеки, як однієї з найвищих соціальних цінностей та показника стабільності, розвитку і процвітання держави.
Органи державної влади, опрацьовуючи отримані за встановленою процедурою звернення громадян, мають взяти для свого використання максимальну кількість інформації, узагальнити їі та зробити висновки як про юридичні недоліки у регулюванні системи забезпечення національної безпеки, так і про обставини (суб'єкти, підстави), що породжують загрози національній безпеці держави. Крім того, на основі зазначених показників має бути побудовано загальний план певної діяльності держави, який охоплює тривалий період, а також визначає спосіб досягнення складної цілі (безпеки держави) - стратегію держави.

Висновки. 3 огляду на викладене, інститут звернень громадян є ефективним засобом зворотного зв'язку між суспільством і владою в контексті реалізації соціальних ініціатив та забезпечення національної безпеки держави.

Лише завдяки вказаному інституту можливим $є$ отримання достовірної та вичерпної інформації про громадські настрої й потреби. При цьому практичне значення отриманої інформації відображається у визначенні й передбаченні на iï основі можливих як внутрішніх, так і зовнішніх загроз національній безпеці держави, виокремленні умов утворення таких загроз, а також у можливості побудови належної моделі дієвого, своєчасного та ефективного реагування системи національної безпеки на вказані загрози.

Використовуючи згадану інформацію повинно здійснюватися формування зовнішніх і внутрішніх стратегій (політики) держави, а також дієвої системи забезпечення національної безпеки.

СПИСОК АІТЕРАТУРИ:

1. Боднар О. Поняття особистої безпеки людини і його структура / О. Боднар. - К.: наук. зап. Ін-ту законодавства Верховної Ради України, 2011. - Вип. 2 (5). - 153 с.

2. Загальна декларація прав людини від 10 грудня 1948 / ООН . - К.: Офіц. вид. - Відомості Верховної Ради, 2008. № 9 - 89 с.

3. Закон України «Про основи національної безпеки України» від 19 червня 2003 року / Верховна Рада України. - К.: Парлам., 2003. -78 с.

4. Конституція України від 28 червня 1996 р. / Верховна Рада України. - К.: Офіц. вид. Відомості Верховної Ради, 1996. - № 30. - 141 с.

5. Методика реагування на виклики, небезпеки та загрози національній безпеці держави: навч. посіб / В. Ю.Богданович, А. І. Семенченко, Д. Я. Кучма, А. В. Дацюк. - К.: НАДУ, 2009. $-40 \mathrm{c}$.

6. Пугачов В. П. Введення в політологію: навч.посібник для студентів вищ.навч.закладів / В. П. Пугачов, А. І. Соловйов. - М.: Аспект-Прес, 1998. - № $3 .-447$ с. 
7. Розова Т. В. Специфіка становлення громадянського суспільства в Україні: Монографія / Т. В. Розова, В. Ю. Барков. - Одеса: Юридична література, 2003. - 336 с.

8. Рощин С. К. Психологічна безпека: новий підхід до безпеки людини, суспільства і держави [Електронний ресурс] / С. К. Рощин, В. А. Соснін // Рос.монітор. - № 67. - 1995. - Pежим доступу до ресурсу: http://www.bookap.by.ru/psywar/grachev/g16.shtm.

9. Ситник Г. П. Державне управління національною безпекою України: монографія / Г. П. Ситник. - К. : НАДУ, 2004. -408 с.

10. Ситник Г.П. Безпека національна / Ситник Г.П. Енциклопедія державного управління: у 8 т. / Нац. акад. держ. упр. при Президентові України; наук.ред. колегія: Ю. В. Ковбасюк (голова) та ін. - К.: НАДУ, 2011. - Т. 1: Теорія державного управління / наук. ред. колегія: В. М. Князєв (співголова), І. В. Розпутенко (співголова) та ін., 2011. - 752 с.

11. Скородумова О.Б. Віртуальна особистість і свобода (до проблеми соціальних джерел розуміння свободи в Інтернеті) / О.Б. Скородумова. - М.: Філософія, 2004. - № 2. -196 с.

12. Стратегія національної безпеки України «Україна у світі, що змінюється»: Указ від 12 лютого 2007 року № 105/ Президент України. - Офіц. вид. - Офіційний вісник України, 2007 - № 11 - 389 c.

\section{REFERENCES:}

1. Bodnar, O. Ponyattya osobystosti bezpeky lyudyny i yoho struktura (The notion of personal human security and its structure). Nauk zap. In-u zakonodavstva Verkhovnoyi Rady Ukrayiny. Kyiv. 2011. 153p.

2. OON, Zahalna deklaratsiya prav lyudyny (Universal Declaration of Human Rights). Vidomosti Verkhovnoyi Rady № 93. Kyiv. 2008.89 p.

3. Verkhovna Rada Ukrayiny, Zakon Ukrayiny «Pro osnovy natsionalnoyi bezpeky Ukrayiny» (Law of Ukraine «On National Security of Ukraine»). Biblioteka ofitsiynykh vydan. Kyiv. 2003. $141 \mathrm{p}$.

4. Verkhovna Rada Ukrayiny, Konstytutsiya Ukrayiny (The Constitution of Ukraine). Vidomosti Verkhovnoyi Rady № 30. Kyiv. 1996.141 p.

5. Bohdanovych V.Y., Kuchma D.Y., Datsiuk A.V. Metodyka reahuvannia na vyklyky, nebezpeky ta zahrozy natsionalnii bezpetsi derzhavy (Methods response to challenges, dangers and threats to national security). Kyiv. 2009. $40 \mathrm{p}$.

6. Pugachev V.P., Soloviev A.I. Vvedenye v polytolohyiu (Introduction to Political Science). Moscow, $1998.447 \mathrm{p}$.

7. Rozova T. V., Barkov V. Y. Spetsyfika stanovlennia hromadianskoho suspilstva v Ukraini (Specificity of civil society in Ukraine). Odesa, 2003. $336 \mathrm{p}$.

8. Roshchyn, S.K., Sosnyn, V.A. Psykholohycheskaya bezopasnost: noviy podhod k bezopasnosty cheloveka, obshchestva i hosudarstva (Psychological safety: a new approach to human security, society and the state). Moscow, 1995. $323 \mathrm{p}$.

9. Sytnyk H. P. Derzhavne upravlinnia natsionalnoiu bezpekoiu Ukrainy (State of the national security of Ukraine). Kyiv. 2004. 408 p.

10. Sytnyk, H.P. Bezpeka natsionalna (National Security). Entsyklopediya derzhavnoho upravlinnya. Vol. 1. Teoriya derzhavnoho upravlinnya. Kyiv. 2011. 752 p.

11. Skorodumova, O.B. Vyrtualnaya lychnost y svoboda (k probleme sotsyokulturnih istokov ponymaniya svobod v Internete) (Virtual identity and freedom (to the problem of social and cultural understanding of the origins of freedom on the Internet)). Vestn. un-ta. Seryya 7. Fylosofyya. Moscow, 2004. 96 p.

12. Prezydent Ukrayiny. Stratehiya natsionalnoy bezpeky Ukrayiny »Ukrayina u sviti, shcho zminyuyetsya»: ukaz vid 12 lyutoho 2007 roku (National Security Strategy of Ukraine «Ukraine in a Changing World»: Decree of 12 February 2007 № 105). Ofitsiynyy visnyk Ukrayiny № 11. Kyiv. 2007. 389 p.

Капуловський Артем Валерійович - аспірант

Національна академія державного управління при Президентові України

Адреса: 03057, м. Київ, вул. Ежена Потьє, 20

E-mail: kapulovskiy_artem@ukr.net

Kapulovskyi Artem Valeriyovych - postgraduate

National academy for public administration under the President of Ukraine

Address: 20, Ezhena Pottier Str., Kyiv, 03057, Ukraine

E-mail: kapulovskiy_artem@ukr.net 